ISSN 2413-0877 Volume 2 (2015) 529

The 3rd International Conference on Biological Science 2013

(The 3rd ICBS-2013)

\title{
BASIC EXPERIMENTS OF CS UPTAKE CAPABILITY FOR Eleocharis acicularis
}

\author{
Akinari Takehara' ${ }^{1}$, Masayuki Sakakibara ${ }^{1}, Y^{2}$ sushi Sato ${ }^{1}$, and Sakae Sano ${ }^{2}$ \\ ${ }^{1}$ Graduate School of Science \& Engineering, Ehime University; \\ ${ }^{2}$ Faculty of Education, Ehime University \\ e-mail : 1411akinari@gmail.com
}

\begin{abstract}
Soil in the Fukushima area has been polluted with the radioactive contaminants such as Cs by the accident of Fukushima Daiichi nuclear power plant in March 2011. Remediation of soil contaminated with radioactive $\mathrm{Cs}$ remains one of the most important problems. Phytoremediation is an environmental remediation technique that takes advantage of plant physiology and metabolism to remove radioactive contaminants. Eleocharis acicularis is well known as heavy metal hyperaccumulator aquatic plant and expected as the strong candidate for application to Phytoremediation of polluted water and soil. In this study, a laboratory experiment was carried out to investigate the potential of E.acicularis for Phytoremediation of radioactive Cs contaminated site. The plants were grown hydroponically and placed in solutions containing $\mathrm{Cs}$ and $\mathrm{K}$ at different concentration (Cs concentration: $5 \mathrm{mg} / \mathrm{L}$, K concentration: $0,0.2,2,5,50,100 \mathrm{mg} / \mathrm{L}$ ) in a period of 21 days.In the experimental results, the highest concentration of Cs was $1560 \mathrm{mg} / \mathrm{kg}$-DW in E. acicularis after 21 days. The concentration of $\mathrm{Cs}$ in plants decreased with the increasing initial concentration of $\mathrm{K}$ in the solution. This results indicate that $E$. acicularis has the ability to accumulate radioactive $\mathrm{Cs}$ from radioactive Cs contaminated soil and water, making it a good candidate species for radioactive Cs Phytoremediation.
\end{abstract}

Key words : Fukushima, Eleocharis acicularis, phytoremediation, Cs

ISSN 2413-0877 (c) 2015 The Authors.

Published by KnowledgeE Publishing Services This is an open access article under the CC BY-NC-ND license (http://creativecommons.org/licenses/by-nc-nd/4.0)

Selection and Peer-review under responsibility of the 3rd ICBS-2013

Doi http://dx.doi.org/10.18502/kls.v2i1.209 